PF 2019 (LXXIII): 571-588

\author{
DAGMARA BANASIAK \\ Instytut Języka Polskiego \\ Uniwersytet Warszawski \\ ul. Krakowskie Przedmieście 26/28 \\ 00-927 Warszawa \\ tel. (+22) 5521021 \\ e-mail: dagmara.m.banasiak@gmail.com
}

\title{
O ZNACZENIU CZASOWNIKA WYŚMIAĆ (KOGOŚ, COŚ) I JEGO UŻYCIU W INTERNETOWYM DYSKURSIE POLITYCZNYM
}

SŁOWA KLUCZOWE: akt mowy, polski internetowy dyskurs polityczny, znaczenie dyskursywne, wyśmiać (kogoś, coś), śmiech

KEYWORDS: act of speech, Polish political discourse on the Internet, discursive meaning, wyśmiać (kogoś, coś) (to mock somebody, to deride somebody), śmiech (laughter)

\section{ON THE MEANING OF THE POLISH VERB WYŚMIAĆ (KOGOŚ, COŚ) (TO MOCK SB, TO DERIDE SB) AND ITS USE IN THE POLISH POLITICAL DISCOURSE ON THE INTERNET}

\begin{abstract}
The present article aims to depict selected structural, syntactic and semantic features of the Polish verb wyśmiać (kogoś, coś) (to mock sb, to deride sb). A context-free meaning of this lexeme is general and broad and can be decribed as 'disapprobation demonstrated with comic forms of expressions'. A usage-based analysis shows that wyśmiać (kogoś, coś) is a speech act verb which requires multiperspective recontextualization including a metaspeaker's point of view, as well as communicational and axiological character of a discourse in which this verb occurs. The article discusses selected aspects of semantics and pragmatics of this entity based on the Polish political discourse on the Internet represented by one political text (news) published on the Polish news portal DoRzeczy.pl. The analysis leads to a conclusion that the verb wyśmiać (kogoś, coś) denotes speech acts whose illocutionary force and perlocutionary consequence has relative value dependent on a recipient's point of view.
\end{abstract}


Mówimy, że wyśmiewamy tego, z kogo śmiejemy się dla okazania wzgardy. (Leibnitz, Tablice definicji, 1975, s. 79)

\section{Wprowadzenie}

W bogatej literaturze przedmiotu na temat komizmu i humoru wyśmiewanie traktowane jest jako przejaw agresji wymierzonej przeciwko ofierze, dotkniętej przez jakąś formę („żądło”) komizmu (por. na ten temat np. Dziemidok 1961, Passi 1980, s. 144-145). W pracach o nachyleniu socjologicznym i psychologicznym wyśmiewanie zalicza się do „zakamuflowanych form agresji językowej” oraz do „form agresji językowej dokonywanej na forum publicznym” (por. np. Peisert 2004, s. 120-132, s. 140-143). W literaturze bywa łączone z komizmem satyry, a w filozofii - z różnymi kierunkami estetycznymi i fenomenologicznymi.

Zadaniem niniejszej pracy jest przyjrzenie się z perspektywy lingwistycznej jednemu z językowych znaków nazywających te zjawiska. Podejmę zatem próbę analizy strukturalnej i semantycznej czasownika wyśmiać (kogoś, coś), a następnie w bardzo ograniczonym zakresie przyjrzę się jego znaczeniu w użyciu, którego szerszy kontekst stanowi polski dyskurs polityczny w Internecie, w którym da się zaobserwować zwiększoną w ostatnich latach aktywność leksemu wyśmiać (kogoś, cośs) , a zarazem kształtowanie się specyficznego znaczenia dyskursywnego tej jednostki. Ze względu na ograniczoną objętość pracy to ostatnie zjawisko omawiam na jednym tylko przykładzie, wybranym spośród wielu podobnego typu użyć, jakie można znaleźć w Internecie.

\section{Baza materiałowa i źródła}

Podstawę materiałową pracy tworzy zbiór 40 artykułów i tzw. newsów, zaczerpniętych $\mathrm{z}$ następujących internetowych portali informacyjnych: DoRzeczy.pl, Niezależna.pl, Onet.pl, Wprost.pl, Wp.pl. Każdy z tych tekstów (opublikowanych od stycznia do września 2018 roku² $^{2}$ zawiera w nagłówku, podtytule lub leadzie dokonany czasownik przechodni wyśmiać (kogoś, coś), użyty w formie czynnej lub biernej. Ich tematyka odnosi się do bieżących (w momencie publikacji tekstu) wydarzeń politycznych, a treść w sposób retrospektywny przywołuje różne elementy konsytuacyjne aktu wyśmiania. Zgromadzony przeze mnie materiał traktuję jako próbki celowo ukształtowanych wypowiedzi funkcjonujących w obrębie

\footnotetext{
Por. punkt 2. tej pracy.

Część z nich została wyekscerpowana za pomocą wyszukiwarki frazeo.pl.
} 
szeroko rozumianego dyskursu medialnego, którego jedną z odmian jest internetowy dyskurs polityczny.

W toku analizy przywołuję również przykłady użyć z Narodowego Korpusu Języka Polskiego i z wyszukiwarki „Google”, zaznaczając każdorazowo źródło cytatu.

\section{O semantyczno-pragmatycznych aspektach czasownika wyśmiać (kogoś, coś) z perspektywy dyskursu}

W tej części artykułu omówię najważniejsze cechy słowotwórcze, semantyczne i składniowe związane z czasownikiem wyśmiać (kogoś, coś), potrzebne do właściwej rekontekstualizacji przykładu przywołanego w następnym punkcie pracy. Wiele wniosków z obecnego fragmentu analizy ma charakter rozpoznawczy i z pewnością wymaga dalszych dociekań3

\subsection{Właściwości słowotwórcze}

Czasownik wyśmiać (kogoś, coś) jest prefiksalnym derywatem dewerbalnym należącym do rozbudowanego gniazda słowotwórczego utworzonego wokół niepodzielnego słowotwórczo, refleksywnego czasownika podstawowego śmiać się. Dosłowne, aktualne znaczenie leksemu śmiać się odnosi się do werbalno-mimicznej (fizjologicznej) reakcji na przeżycie komiczne, które nie jest wywołane intencjonalnymi działaniami ideowo-emocjonalnymi skierowanymi przeciwko komuś, a uczuciem odprężającego rozbawienia, pozbawionego refleksji i deprecjonującej oceny na temat kogoś lub czegoś. Por. podaną w USJP definicję śmiać się oraz przykładowe konteksty:

wydawane przez człowieka charakterystyczne odgłosy, dźwięki typu ha ha ha, he he $h e, h i$ hi hi, którym towarzyszy drgający ruch mięśni twarzy oraz powtarzający się skurcz przepony, zwykle będące objawem wesołości ${ }^{4}$.

\footnotetext{
3 Za wspólny namysł nad semantyką czasownika wyśmiać (kogoś, coś) pragnę podziękować uczestnikom środowych konwersatoriów Dociekania semantyczne odbywających się rokrocznie na Wydziale Polonistyki Uniwersytetu Warszawskiego.

${ }_{4}$ Definicje słownikowe czasownika śmiać się oceniam jako mało przydatne w charakterystyce semantycznej tego verbum - ograniczają śmiech do werbalno-mimicznej ekspresji (poza ISJP, który czyni komponent reakcji genus proximum leksemu śmiać się) pozytywnych afektów (wesołości lub radości). Nie uwzględniają roli komizmu jako właściwego czynnika doprowadzającego do odpowiedniej reakcji psychofizycznej. O problemach w definiowaniu czasownika śmiać się i jego derywatu rzeczownikowego śmiech piszę w artykule Rozwój semantyczny leksemów „śmiać się”, „śmiech” [w:] Komizm historyczny, t. VIII, s. 59-73.
} 
Bartek dostał ataku śmiechu. Śmiał się tak długo i tak głośno, że zaraził tym śmiechem wszystkich Allian, a jego echo niosło się teraz przez Wokark i odbijało od wysokich murów Lewawu (NKJP).

Tam już ktoś za plecami Romana śmiał się ubawiony tą sceną (...) (NKJP).

Sens ten jest podstawą licznych przesunięć metonimicznych, prowadzących do rozszerzeń semantycznych i ukształtowania się kilku wtórnych znaczeń czasownika śmiać się o różnych właściwościach gramatycznych, różnym stopniu leksykalizacji we współczesnej polszczyźnie oraz dużej zależności kontekstowej5. Należy do nich m.in. dobrze ustabilizowane znaczenie 'dezaprobaty wyrażanej za pomocą komizmu', wyodrębniane przez leksykografów we wszystkich powojennych słownikach języka polskiego ${ }^{6}$. Jest ono często eksplikowane w nich (nb. błędnie) za pomocą ciągów synonimicznych typu: 'wyśmiewać się, żartować, kpić z kogoś, czegoś' (por. np. USJP)7. Najprostszą semantycznie jednostką językową realizującą ten właśnie sens jest nieprzechodni, refleksywny czasownik śmiać się (z kogoś, czegoś), że_, por. przykłady użyć:

Wcześniej pojawiała się wersja, że Krzysztof miał zabić brata, bo ten śmiał się z niego, że nie ma dziewczyny. Nie udało się potwierdzić takiego motywu (NKJP).

$W$ latach dziewięćdziesiątych cała Polska śmiała się z biznesmenów w białych skarpetkach, w Mercedesach i z komórami w dłoni (NKJP).

Przywołany wyżej leksem jest bazą słowotwórczą dla licznych prefigowanych formacji słowotwórczych, w tym czasownika dokonanego wyśmiać (kogoś, coś), będącego przedmiotem opisu mojej pracy $^{8}$. Śmianie się w przypadku struktury semantycznej zarówno czasownika śmiać się ( $z$ kogoś, czegoś), jak i wyśmiać (kogoś, coś) nie ma znaczenia aktualnego - oznacza złożony, jednostkowy i niepowtarzalny układ sytuacyjny opisujący komiczne działania agensa, których tematem jest druga osoba lub jakaś jej właściwość, własność. Por. przykłady:

Zagadnienie wieloznaczności czasownika śmiać się, wpływu otoczenia składniowego i konsytuacyjnego na semantykę tego verbum oraz mechanizmu metonimii organizującego w sposób gramatyczny i semantyczny całą rodzinę derywatów formalnych i semantycznych czasownika śmiać się omawiam szczegółowo w: Banasiak, w przygotowaniu.

6 O domniemanych relacjach etymologicznych między znaczeniem dosłownym śmiechu („werbalno-mimicznym”) a „dezaprobującym” piszę w: Banasiak, ibidem.

7 Definicja synonimiczna oczywiście nie zdaje sprawy ze struktury znaczeniowej tego leksemu i ma charakter tautologiczny. Bliskoznaczniki wchodzące w jej skład często definiowane są również przez przywołanie zestawu tych samych czasowników, co tworzy piętro błędnych kół definicyjnych.

8 Por. zbiór pozostałych derywatów oznaczające dezaprobatę wyrażaną za pomocą środków komicznych: naśmiewać się (z kogoś, czegoś), obśmiać (kogoś, coś), obśmiewać (kogoś, coś), podśmiewać się (z kogoś, czegoś), wyśmiać się (z kogoś, czegoś), wyśmiewać (kogoś, coś), wyśmiewać się (z kogoś, czegoś). 
Wyśmiali go już na pierwszym dniu (szkoły - przypis D.B.), przezwali „grubym pajacem", a potem to już wiesz, poszło dalej (NKJP).

Rozpoczęło się ośmieszanie Dawida i jego tekstu przed resztą klasy. Wychowawczyni wyśmiała fragmenty wypracowania (przytaczam je - przyp. D.B.: W związku z ogólnym rozprzężeniem, jakie panuje ostatnio w naszej szkole, w dniach 23-25 maja wraz $\mathrm{z}$ całą klasą miałem przyjemność uczestniczyć w z dawna oczekiwanej wycieczce do stolicy. Po 7 godzinach wyczerpującej podróży w ciągle rosnącym skwarze naszym oczom ukazała się upragniona tablica z napisem „Warszawa”.) i poradziła naszemu synowi, abyśmy napisali mu zwolnienie, by już nie pojawiał się więcej w szkole. Dawid bardzo przeżył krytykę ze strony nauczycieli (...).

Autorzy Gramatyki współczesnego języka polskiego. Morfologia (dalej: GWJPM) zaliczają derywat wyśmiać (kogoś, coś) do „formacji zmieniających perspektywę funkcjonalną zdarzeń" (GWJPM 1999, s. 553) ze względu na zmianę wymagań rekcyjnych w stosunku do podstawy - czasownik śmiać się (z kogoś, czegoś) przyłącza obiekt czynności w formie dopełniacza za pomocą przyimka $z$, zaś jego derywat bezprzyimkowo w formie biernika ( $\mathrm{z}$ dezintegracją morfemu się). Zmiana ta powoduje również, że derywat staje się przechodni. Wprowadza ją formant prefiksalny $w y$-, który, według autorów GWJPM, oprócz formalnosyntaktycznej, pełni również funkcję semantyczną - wnosi do podstawy znaczenie „wyrażania aktywnego stosunku subiektu do wyróżnionego obiektu (przedmiotowego lub zdarzeniowego) przy kompletnym, wyczerpującym wykonywaniu akcji podstawowej” (GWJPM 1999, s. 553). Sądzę, że kompletność wykonanej akcji w przypadku semantyki derywatu wyśmiać (kogoś, coś) należy rozpatrywać w aspekcie siły i konsekwencji prześmiewczych działań agensa, znieważających, wykluczających z grupy, a przez to wywołujących w obiekcie negatywne stany emocjonalne. Zdania typu:

Śmiał się z jej nosa trochę.

Wyśmiał jej nos trochę. (?)

potwierdzają znaczenie derywatu związane z 'wysoką efektywnością akcji oznaczanej podstawą, jej gruntowność, doprowadzenie do końca’. Wątpliwości może jednak budzić bezwzględne przypisywanie prefiksowi tej funkcji semantycznej, jak czynią autorzy GWJPM. Sądzę, że wprowadza ją perfektywizacja, a formant zachowuje swoje przestrzenne, ablatywne znaczenie, najlepiej widoczne na przykładzie czasowników ruchu, oznaczające kierunek akcji z ograniczonego fragmentu przestrzeni poza ten fragment (np. ciagnać - wyciagnać, kopać - wykopać). W wypadku czasownika wyśmiać (kogoś, coś) oznaczającego emocjonalno-intelektualną postawę wobec kogoś ruch ten ma charakter operacji myślowej, polegającej - jak sądzę - na wydzieleniu, wyodrębnieniu obiektu z osobowego zbioru poprzez dezaprobatę wyrażoną wprost śmiechem lub zawoalowaną działaniami 
komicznymi (por. Rudzka-Ostyn 1985, s. 209-241). Wyodrębnienie to odbywa się ze względu na jakąś właściwość obiektu, która - zdaniem wyśmiewającego zasługuje na „upublicznienie”, mające na celu podważenie pozycji wyśmianego w danej społeczności i/lub wykluczenie go z niej ${ }^{9}$.

\subsection{Właściwości składniowe}

Kształt fonetyczny wyśmiać funkcjonuje najczęściej w dwóch układach predykatowo-argumentowych: 1) przyłączając dopełnienie zdaniowe za pomocą spójnika $\dot{z} e$, wprowadzające na prawach cytatu zdanie stanowiące rematyczne dictum wypowiedzi: [ktoś ${ }_{i}$ wyśmiał [kogoś], że_, por przykłady:

(...) nie zareagowali na słowa ojca, wyśmiali go, że chciałby trzymać chłopaka przy mamusinej spódnicy, (...) (WSJP).

Całkowicie wyśmiano nasze sugestie, że w przyszłości Ławica powinna oferować loty do Ameryki Północnej (NKJP).

Koleżanki z pracy mnie wyśmiały, że na święta kupuję gotowe potrawy ${ }^{10}$.

2) przyłączając dopełnienie w formie nominalizacji (kondensujących odrębne SPA) za pomocą przyimka $z a$, informującego o przyczynie wyśmiania [ktoś.] wyśmiat [kogoś]

$z a\left[\operatorname{coś}_{p}\right]$ - por. przykłady:

Przeczytałem w ogólnopolskiej gazecie, że wybrano najgłupszych Amerykanów. Drugi rok z rzędu ten mało zaszczytny tytuł przyznano Michaelowi Jacksonowi. Takie miano nadawane jest corocznie $\mathrm{z}$ okazji 1 kwietnia. W zeszłym roku piosenkarza $\mathrm{w}$ ten sposób wyśmiano za groźny wybryk - kiedy to wystawił swoje dziecko za barierkę hotelowego balkonu w Berlinie (NKJP).

Krystyna Pawłowicz po raz kolejny przekroczyła granice dobrego smaku i kultury, kiedy oświadczyła, że w Sejmie śmierdzi przez protestujących niepełnosprawnych i ich opiekunów. Za te słowa została jawnie wyśmiana przez społeczeństwo, a głos w tej sprawie zabrał również słynny profesor Gadacz ${ }^{11}$.

Możliwe są różne składniowe kombinacje i warianty tych struktur (np. [ktoś] wyśmial [kogośs] za to, że_, [ktoś] wyśmiał [kogośj], bo_) oraz przekształcenia dopełnienia, które może być teleskopowo rozwijane w postaci osobnego wypowiedzenia lub sekwencji wypowiedzeń, por.:

9 Argument ablatywny w przypadku derywatu wyśmiać (kogoś, coś) jest zatarty, to znaczy nie jest wyrażany na powierzchni w funkcji argumentu w konstrukcjach typu *an wyśmiał Marię z całej grupy.

10 Zob. https://kobieta.wp.pl/kolezanki-z-pracy-mnie-wysmialy-ze-na-swieta-kupuje-gotowe -potrawy (dostęp: styczeń 2019 r.).

11 Zob. https://pikio.pl/krystyna-pawlowicz-smierdzi/ (dostęp: styczeń 2019 r.). 
Wspomniałam i ojcu Magdy, że jego córka jest zaangażowana uczuciowo. Wyśmiał mnie. - Chyba już nie masz innych zmartwień? Jak się kocha, to się odkocha i po kłopocie. I bardzo dobrze, że ma wreszcie chłopaka, już się obawiałem, że objawi ochotę wstąpienia do karmelitanek bosych albo innego równie czcigodnego zakonnego zgromadzenia (NKJP).

Predykat ten otwiera trzy pozycje argumentowe o określonych wartościach: lewostronny argument osobowy $\mathrm{w}$ roli agensa wyśmiewania ${ }^{12}$, prawostronny argument osobowy (powierzchniowo przedmiotowy) w roli obiektu (pacjensa $)^{13}$, prawostronny argument zdarzeniowy, opisujący przyczynę akcji aktualnej, realizowany często za pomocą nominalizacji kumulujących odrębne struktury predykatowo-argumentowe lub za pomocą danych wyrażanych innym kodem semiotycznym.

Argument przewidziany dla osobowego odbiorcy (odbiorców) akcji może wystąpić na powierzchni, jeśli nadawca chce z potrzeb komunikacyjnych wyspecyfikować czy wyróżnić odbiorców danego komunikatu. Wydaje się, że jest on zawarty implicite w znaczeniu predykatu - obecność odbiorców w akcie wyśmiania wynika z intencji agensa, o której będzie mowa w dalszej części rozważań. Zdania typu:

Jan wyśmiał Marię i jednocześnie nikt tego nie widział.

Jan wyśmiał Marię i jednocześnie nikt o tym nie wie.

nie są sprzeczne ze względu na ustanawiającą i autoryzującą rolę metanadawcy, będącego jednocześnie odbiorcą komunikatu. Może być nim także sam wyśmiany.

Argument odbiorcy może być realizowany przez dwie różne konstrukcje gramatyczne: 1) wyrażenia przyimkowe wskazujące wprost lub metonimicznie na osobowego odbiorce (do + gen, przy + loc, przed + loc) oraz 2) wyrażenia przyimkowe o znaczeniu lokatywnym suponujące informację o zajściu aktu w obecności rzeczywistych lub wirtualnych odbiorców lub określenia przysłówkowe. Oto przykłady:

12 Predykat tworzy niekoherentne połączenia $\mathrm{z}$ argumentami o znaczeniu przedmiotowym w rolach wykonawcy lub obiektu wyśmiewania, por.: ${ }^{\star}$ Stół wyśmiał Marię, ${ }^{*}$ Maria wyśmiała las, *Niemowlę wyśmiało matkę, ${ }^{*}$ Pies wyśmiał mnie. Sugeruje to, że agens musi być istotą mówiącą, zdolną do poznawczego reflektowania i odczuwania, ale (chyba) niekoniecznie świadomą negatywnych skutków swoich działań. Przywodzi to na myśl chociażby częste sytuacje wyśmiewania w grupach wczesnoszkolnych. Jest to z pewnością aspekt wymagający osobnej uwagi. O obiekcie - patrz przyp. 13.

13 Zdanie ${ }^{\star} J a n$ wyśmiał nos Marii i jednocześnie nie wyśmiał Marii pokazuje, że na powierzchni obiekt może mieć wartość pozornie przedmiotową (quasi-przedmiotową). W strukturze głębokiej argument ten ma wartość osobową. Pozornie przedmiotowe obiekty wyśmiewania są połączone różnymi relacjami z właściwym obiektem czynności, dlatego zdanie Jan wyśmiał mój las nie jest sprzeczne w przeciwieństwie do *Jan wyśmiał las. 
Junker [sic!] wyśmiał Tuska przy Trumpie ${ }^{14}$.

Znajomi wyśmiali mój makijaż na Facebooku (NKJP).

Zostałam wyśmiana przez nauczycielkę przed całą klasą (zasłyszane).

Wielkiego pecha miał jeden z panów, który zagłosował wbrew sympatiom swej żony. Jego karta wyborcza została podarta, a on sam publicznie wyśmiany (NKJP).

\subsection{Właściwości semantyczne}

Czasownik wyśmiać (kogoś, coś) należy do klasy leksemów nazywających działania o charakterze komicznym wyrażające negatywne etycznie zachowania i relacje osobowe ${ }^{15}$. W ogólnych słownikach języka polskiego czasownik wyśmiać (kogoś, coś) jest definiowany w następujący sposób:

ISJP: 1 jeśli ktoś wyśmiał kogoś lub coś, to krytycznie ocenił tę osobę lub rzecz i ośmieszył ją

USJP: odnieść się do kogoś, czegoś drwiąco, z szyderstwem, wytykając wady i słabości; wykpić

WSJP: śmiejąc się, wyrazić swoją negatywną ocenę jakiejś osoby lub tego, co ta osoba zrobiła.

Eksplikacje te niewątpliwie mają zbyt ogólny i ubogi charakter ${ }^{16}$. Wydobywają przede wszystkim konstytutywny komponent semantyczny - dezaprobaty - zawarty w strukturze znaczeniowej predykatu wyśmiać (kogoś, coś). Obecność semu dezaprobaty potwierdzają także spreparowane zdania sprzeczne, np.

*Jan skomplementował nos Marii, wyśmiewając go.

*Jan wyśmiał książkę Marii, chwaląc ją za treść.

Dezaprobujący sąd wyśmiewającego ma złożoną strukturę: jest wynikiem zaistnienia przeżycia emocjonalno-intelektualnego w umyśle wyśmiewającego, na które wpływa wiele rozmaitych czynników sytuacyjnych, społecznych i osobowościowych, np. indywidualne relacje wyśmiewającego z wyśmiewanym, sympatie i antypatie, kontakty interpersonalne oraz hierarchia w danej grupie społecznej, aksjosfera obowiązująca w danej społeczności, kwestie osobowościowe (skłonność

14 Zob. https://www.youtube.com/watch?v=56rs3NS-D34 (dostęp: wrzesień 2017 r.).

15 W charakterystyce tej klasy leksemów korzystam z opracowania Macieja Grochowskiego (1982). Zawężam jednak jej zasięg do działań wyrażających negatywne etycznie relacje osobowe za pomocą środków komicznych i rozszerzam o składnik zachowania wprowadzający informacje dotyczące określonego scenariusza postępowania agensa podporządkowanego jego woli i intencjom.

16 Definicje te mogłyby odnosić się równie dobrze do bliskoznaczników czasownika $w y$ śmiać (kogoś, coś), np. kpić, drwić, szydzić. 
do inicjowania konfliktów, poczucie humoru, niska empatia, trudności z funkcjonowaniem w społecznościach, nieznajomość norm społecznych (por. Peisert 2004, s. 154-165). Posługując się klasyfikacją czasowników uczuć Nowakowskiej-Kempnej (1986), wyśmiewanie można potraktować jako wyraz uczuć-postaw. Postaw, ponieważ wynika ono z dobrowolnie przyjętego (świadomie lub nie), subiektywnego systemu przekonań i opinii, które mają charakter względnie trwałych dyspozycji osobowościowych. Uczuć, ponieważ uczucia takie, jak niechęć, gniew, oburzenie czy pogarda, będące impulsem inicjującym wyśmiewanie, są niestałymi reakcjami afektywnymi, wywołanymi konfliktem postaw światopoglądowych zachodzącym między uczestnikami aktu wyśmiania.

Dyskredytujący sąd wyśmiewającego nie ma charakteru obiektywnego i omnipotencjalnego ${ }^{17}$ - wynika z subiektywnego systemu wartości i przekonań drwiącego, jego preferencji, schematów aksjologicznych panujących w danych społecznościach. Jest natomiast sądem wartościującym, będącym wyrazem różnego typu przekonań agensa (etycznych, estetycznych, ideologicznych, moralnych, teologicznych, politycznych i in.). Nie opisuje przy tym stanu rzeczy na drodze logicznego wnioskowania, tylko informuje o stosunku agensa do kogoś. Wymyka się też testom sprawdzalności logicznej, prowadzącej do falsyfikacji lub konfirmacji. Dlatego też sąd ten odznacza się dwiema zasadniczymi cechami. Często ma ambiwalentną strukturę polegającą na negatywnej ocenie stanu rzeczy, który jest lub mógłby być uznany przez kogoś innego za pozytywny - por. spójność przykładowych zdań: Jan wyśmiał sukces Marii i Jan wyśmiał ładny nos Marii. Druga właściwość wyraża się w tym, że podlegające owemu sądowi obiekty zasadniczo nie poddają się ograniczeniom selekcyjnym i dlatego też wymykają się sztywnym typologizacjom. Na podstawie analizy cytatów z NKJP można mówić jedynie o określaniu topiki wyśmiewania, odnoszącej się do najrozmaitszych cech związanych z powierzchownością, osobowością, umysłowością, zachowaniami czy działaniami człowieka.

Poznawczy wymiar formułowania wartościujących sądów wyśmiewającego jest kwestią wymagającą odrębnego studium, głównie pozajęzykowego. Stoją za nim (wykluczając pobudki czysto emocjonalne i interpersonalne) procesy mentalne związane najogólniej z kategoryzowaniem i schematyzowaniem rzeczywistości oraz pojmowaniem jej w relacji do pojęcia normy.

Wyśmiewający wyraża swoją dyskredytującą ocenę i tym samym nieprzyjazną postawę wobec kogoś w sposób niebezpośredni, zawoalowany działaniami komicznymi. Komiczne konceptualizacje bywają demonstrowane w sposób prosty lub bardziej „wyrafinowany”, kiedy wyśmiewający sięga po różne tropy

17 Może być jednak wspólny dla jakiejś społeczności (formalnej lub nieformalnej) związanej wspólnotą norm moralnych, religijnych, światopoglądowych. 
retoryczne, konstruując swój prześmiewczy komunikat. Często opiera go na technikach parodiowania, karykaturowania, trawestowania, ironizowania na temat wyśmianego czy atakowania go, używając sarkazmu.

Obserwacja materiału zgromadzonego na potrzeby mojej pracy pokazuje, że manifestacja komicznej dezaprobaty może odbywać się w zróżnicowany sposób:

a) werbalnie, np. za pomocą różnorakich kalamburów językowych, adideacji, paragramów, amplifikacyjnego użycia nacechowanych ekspresywnie środków językowych (deminutywów, augementatywów, pejoratywów, kolokwializmów), wypowiedzi opartych na absurdalnych porównaniach, zestawieniach czy aluzjach;

b) niewerbalnie, zwłaszcza za pomocą pozawerbalnych środków wizualnych i słuchowych, prozodycznych, parajęzykowych, gestycznych;

c) zarówno werbalnie, jak i niewerbalnie.

Wynika to ze struktury semantycznej czasownika wyśmiać (kogoś, coś), który, posługując się klasyfikacją Zbigniewa Grenia, należy do pierwszej grupy verbów dicendi sensu largo (por. Greń 1994, s. 22). I tak, nie łączy się z wyrażeniami typu milcząc/milcząco/w milczeniu, por. budzące wątpliwości zdanie: Jan, milcząc, wyśmiat posturę Marii. Łączy się zaś z wyrażeniami odnoszącymi się do innych niż akustyczny kanałów przekazywania informacji (por. Greń 1994, s. 24), co widać w akceptowalnych wypowiedziach:

Jan wyśmiał Marię, naśladując sposób jej chodzenia.

Jan wyśmiał Marię, rysując jej posturę.

oraz nie tworzy pleonazmu w kolokacji z frazą mówiąc:

Jan wyśmiał Marię, mówiąc, że z taką figurą może co najwyżej zostać miss gminy.

Z kolei brak nadwyżki znaczeniowej w połączeniu czasownika wyśmiać (kogoś, coś) z rzeczownikiem śmiech (w znaczeniu aktualnym) pokazuje, że negatywna ocena wyśmiewającego może być komunikowana również parajęzykowo:

Jan wyśmiał Marię szyderczym śmiechem ${ }^{18}$.

W prześmiewcze działania agensa wpisana jest niemoralna, zaczepna intencja. Dowodzi tego niezborność poniższych zdań:

*Jan wyśmiał Marię w dobrej wierze.

18 Opis sposobów demonstrowania deprecjonującej oceny wyśmiewającego z pewnością zasługuje na osobną uwagę i wymaga analizy uwzględniającej nie tylko materiał językowy. Ogląd nawet niewielkiej próby badawczej pozwala zauważyć wysoce zróżnicowaną kombinatorykę środków i kodów służących do komunikowania prześmiewczego sądu, do której dostęp wyłącznie poprzez dane językowe może być ograniczony. 
*Jan nie chciał zaszkodzić Marii, tylko ją wyśmiał.

*Jan wyśmiał książkę Marii i jednocześnie nie chce, by inni wiedzieli, że książka Marii jest w mniemaniu Jana słaba.

Wyśmiewający posługuje się komizmem w jego nieprymarnej funkcji społecznej, to znaczy nie w funkcji antyagresywnej i antyhierarchicznej, w której komizm służy wspólnej zabawie, jednoczy we wspólnym śmiechu, neutralizuje rzeczywiste lub wyimaginowane podziały społeczne (więcej na temat prymarnej funkcji komizmu w: Dziemidok 1961). Przeciwnie - wyśmiewający występuje przeciwko komuś po to, by poniżyć godność jego osoby, wywołać w nim negatywne stany emocjonalne albo też podtrzymać jednostkowy lub grupowy konflikt itp. Chce narzucić odbiorcom złą opinię o obiekcie i spowodować, że przez wyśmianą właściwość będzie on oceniany gorzej, niż oceniany byłby, gdyby o tej cesze odbiorcy nie wiedzieli. Często robi to, mając na uwadze własne korzyści społeczne, materialne, interpersonalne, które może osiągnąć, osłabiając reputację czy pozycję wyśmianego. Dlatego wyśmiewający stawia się w roli demaskatora negatywnych - z punktu widzenia jego przekonań i opinii - działań i właściwości wyśmianego. Chce, by inni podzielali jego sąd, a swoich sojuszników zjednuje we wspólnej zabawie z drugiego - po to też sięga po środki komiczne ${ }^{19}$.

\subsection{Właściwości pragmatyczne}

Czasownik wyśmiać (kogoś, coś) oznacza akty mowy lub, szerzej, akty komunikacyjne, których pełne zrozumienie wymaga przywołania dostępnych kontekstów: językowego, konsytuacyjnego, interpersonalnego, dyskursywnego. Jak w przypadku wszystkich czasowników oznaczających akty mowy, tak też w wypadku wyśmiać (kogoś, coś) mamy do czynienia de facto z dwiema wypowiedziami: agensa (autora wypowiedzi nazywanej wyśmianiem) i metanadawcy (aktualnie mówiącego, referenta aktu wyśmiania).

W tekstach stanowiących bazę materiałową niniejszej pracy leksem wyśmiać (kogoś, coś) występuje wyłącznie w formie 3 os. l. poj. i mn., najczęściej w stronie czynnej w czasie przeszłym. Jest to zapewne podyktowane wymogami gatunkowymi artykułów, newsów, w których trzecioosobowa perspektywa narracyjna jest podporządkowana funkcji sprawozdawczo-informacyjnej tych tekstów. To na metanadawcy (autorze artykułu) spoczywa zatem rola nominalna i typologiczna - na postawie danych werbalnych i pozawerbalnych, które retrospektywnie przywołuje i opisuje w formie mowy zależnej i/lub niezależnej, interpretuje on dany akt komunikacyjny i nazywa go wyśmianiem.

19 W tym miejscu nasuwa się pytanie o świadomość działań agensa, które na tym etapie analiz pozostawiam otwarte. 
W przeważającej części przebadanego przeze mnie materiału metanadawca stronniczo (i często hiperbolizująco) referuje akt wyśmiania, to znaczy suponując swoją ocenę odnoszącą się do zasadności danego aktu i działań jego agensa. Najczęściej opowiada się po stronie wyśmiewającego lub wyśmiewających. Robi to za pomocą różnych środków - leksykalnych, tekstotwórczych, pozajęzykowych (nierzadko z satysfakcją, triumfująco i kontynuując prześmiewczy ton agensa):

Kreatywna działalność polityka spotkała się w Internecie z krytyką oraz - jak nietrudno było przewidzieć - została wyśmiana przez wielu użytkowników Sieci.

Cały świat WYŚMIAŁ Wałęsę za strój na pogrzebie Busha! (...) „Noblista OSZALAŁ. Ubrał się jak na ryby" - czytamy w Kanadyjskich mediach ${ }^{20}$.

Pomiędzy metanadawcą a agensem nie musi istnieć zgoda co do zasadności nazwania danego aktu wyśmianiem - metanadawca może zaklasyfikować daną wypowiedź jako wyśmiewanie zarówno wtedy, gdy w mniemaniu agensa nie była ona prześmiewcza, jak i wtedy, gdy agens w ogóle nie wyrazi tego, co mogłoby być nazwane wyśmianiem.

Wpływ metanadawcy na strukturę treściową, układ aksjologiczny aktu wyśmiania i jego wartość illokucyjną jest zatem istotny, o ile nie decydujący, przynajmniej w części przykładów.

\section{Studium przypadku}

Przejdę teraz do analizy materiału tekstowego, której celem jest omówienie najważniejszych składników konstytuujących semantykę danego aktu wyśmiania oraz sposobu, w jaki modelowane jest znaczenie dyskursywne badanego leksemu. Uczynię to na przykładzie artykułu (newsa?) ${ }^{21}$ opublikowanego 13 lipca 2018 roku w portalu internetowym DoRzeczy.pl ${ }^{22}$. Dla przejrzystości wywodu zdekomponuję strukturę tego tekstu, ale ze względu na ograniczoną objętość pracy omówię jedynie wybrane jego partie ${ }^{23}$.

Makrokontekst społeczno-polityczny analizowanego newsa tworzą czas samorządowej kampanii wyborczej w Polsce w 2018 roku i rywalizacja o prezydenturę

20 Zob. https://wyborcza24.pl/caly-swiat-wysmial-walese-za-stroj-na-pogrzebie-busha/ (dostęp: grudzień 2018 r.).

${ }_{21}$ Jak pokaże dalsza część wywodu, można spekulować na temat gatunku prasowego, w obrębie którego funkcjonują ten i podobne teksty. Należą one raczej do newsów niż do artykułów prasowych.

22 Zob. https://dorzeczy.pl/kraj/70429/Internauci-wysmiali-pompatyczny-wpis-Trzaskowskiego-Moj-tata-uczyl-mnie-obierac-ziemniaki.html (dostęp: lipiec 2018 r.).

23 Pominę kilka przykładów ilustrujących działania wyśmiewających internautów i zdjęcie Rafała Trzaskowskiego zamieszczone tuż po nagłówku. 
Warszawy, głównie pomiędzy kandydatem PiS-u Patrykiem Jakim a Rafałem Trzaskowskim z PO. Mikrokontekst zaś, czyli bezpośrednia konsytuacja aktu wyśmiania, to okoliczności związane z uczczeniem dziesiątej rocznicy śmierci ministra spraw zagranicznych Bronisława Geremka. Informuje o tym w leadzie autor tekstu (metanadawca, referent aktu wyśmiania).

Czasownik wyśmiać (kogoś, coś) występuje w analizowanej publikacji jednokrotnie w strategicznym ze względów komunikacyjnych miejscu - w nagłówku, który przyjmuje postać dwóch wypowiedzeń zdaniowych, por.:

\section{Internauci wyśmiali pompatyczny wpis Trzaskowskiego. "Mój tata uczył mnie obierać ziemniaki..."}

Pierwsze ze zdań pełni funkcję streszczającą news i konstatującą fakt zajścia aktu wyśmiania (jest to informacja stematyzowana). Drugie stanowi fragment prześmiewczej wypowiedzi jednego $\mathrm{z}$ agensów wyśmiania ${ }^{24}$. Jego urwana postać może być odczytana jako celowy zabieg będący zachętą do przyłączenia się do prześmiewczej zabawy internautów pod warunkiem „kliknięcia” i zdecydowania się na przeczytanie całości tekstu.

W nagłówku nie są zrealizowane wszystkie pozycje argumentowe otwierane przez predykat wyśmiać (kogoś, coś) - uwaga czytelników została skupiona na agensie czynności wyrażonym rzeczownikiem zbiorowym internauci, obiekcie wyśmiania (wpis Trzaskowskiego) o wartości powierzchniowo-przedmiotowej (a w strukturze głębokiej - osobowej) oraz argumencie rozwijającym informacje na temat sposobu wyśmiania w formie aluzyjnego, niejednoznacznego cytatu pochodzącego z wypowiedzi jednego z agensów. Argument zdarzeniowy opisujący przyczynę wyśmiania występuje w dalszej części tekstu, a jego brak w tytule ma skłonić czytelników do dalszej lektury. Jest on przywołany w formie zdjęcia wpisu zamieszczonego przez Trzaskowskiego w portalu społecznościowym:

24 Dowiadujemy się o tym dopiero po lekturze całości. Cytat ten może być potraktowany jako wyimek z wpisu Trzaskowskiego, a więc jako zawartość argumentu wyrażającego przyczynę aktu wyśmiania. 


\section{Rafał Trzaskowski $\odot$}

około 2 mies. temu

Bronisław Geremek uczył mnie Cywilizacji europejskiej w Kolegium Europejskim w Natolinie, po francusku. Był poważny, zadumany i srogi. Dostałem najwyższą notę na roku, bo mój ówczesny francuski nie pozwolił na oratorskie popisy i zmusił do wypowiedzi chłodnej, precyzyjnej i oszczędnej. Profesor lubił konkret. Pamiętam, że referowałem credo Edgara Morina z „Penser l'Europe”. Czułem się, jakbym zdawał egzamin życia u biblijnego patriarchy z obrazów Rembrandta. Książkę zrozumiałem 10 lat później. A kiedy w 2015 roku wręczałem Edgarowi Morinowi nagrodę na szczycie ministrów europejskich Trójkąta Weimarskiego w Paryżu, miałem nieodparte wrażenie, że z obrazów zawieszonych na ścianie pałacu przy Quai d'Orsay spogląda na mnie lekko rozbawiony profesor. A jednak warto było czytać Morina.

I 1,9 tys. $603 \rightarrow 610$

I poprzedzony następującym komentarzem metanadawcy:

Rafał Trzaskowski, kandydat PO na prezydenta Warszawy postanowił uczcić rocznicę śmierci Bronisława Geremka zamieszczając wpis na Facebooku. W fakcie tym nie ma nic złego, jednak wydaje się, że polityk Platformy delikatnie przesadził. Internauci wytykają mu przesadną pompatyczność i nadęcie. Wielu nie podoba się fakt, że Trzaskowski zamiast skupić się na osobie Geremka, chwali głównie sam siebie.

W ostatniej części tekstu metanadawca przytacza w formie zdjęcia kilka komentarzy internautów, które, jego zdaniem, składają się na akt wyśmiania. Jednym z nich jest fragment prześmiewczej wypowiedzi posługującej się techniką trawestacji, naśladującej strukturę i patetyczny styl wpisu Trzaskowskiego, ale wykorzystującej błahą tematykę - naukę obierania ziemniaków, osadzoną w lokalnych realiach. Za pomocą tych zabiegów wyśmiewający eksponuje i neguje nieadekwatny styl wspomnienia Trzaskowskiego i, jego zdaniem, snobistyczne intencje autora, dążącego do pokazania swojej erudycji w czasie kampanii wyborczej pod pretekstem uczczenia pamięci swojego wykładowcy:

Skomentował(a) publiczny post Rafał Trzaskowski

Marcin Makowski Mój tata uczył mnie jak obierać ziemniaki na osiedlu Pyrzyckim w Stargardzie, mówił normalnie, po polsku. Był poważny, zadumany i srogi, jak zawsze, gdy zabiera... Zobacz więcej

Lubiẹ to! - 64 odpowiedzi - B 2041 - około 2 mies. temu - edytowano 
Inna wypowiedź konstytuująca akt wyśmiania opiera się na ironicznym powtórzeniu słów Trzaskowskiego - nie w intencji pokornego wyznania słabości wobec wielkiego dzieła literackiego, jak w oryginale, ale w celu podważenia inteligencji prezydenta, podkreślając, że zrozumienie książki zajęło mu aż dziesięć lat. Dyskredytująca puenta komiczna zawarta jest w słowie miszcz. Błędny (z punktu widzenia ogólnopolskiej normy wymawianiowej), bo oparty na uproszczeniu grupy spółgłoskowej, zapis tego wyrazu sugeruje, że Trzaskowski nie jest prawdziwym mistrzem w myśl ikonicznej prawidłowości, że to, co zawiera jakąś usterkę, jest gorsze, niepełne. Źle zapisane słowo denotuje niedoskonały obiekt ${ }^{25}$ :

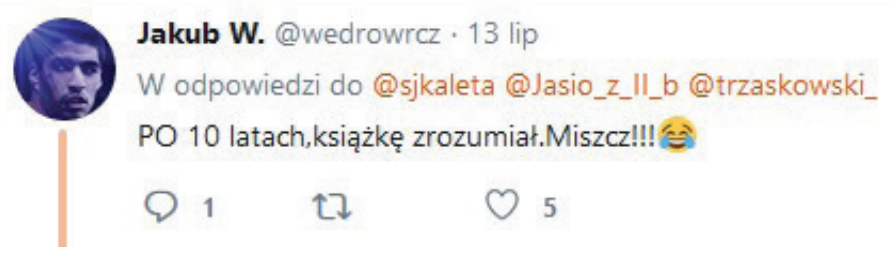

Metanadawca aktu wyśmiania jawnie wyraża swoją ocenę co do zasadności prześmiewczych działań agensów. Świadczy o tym nagromadzenie wyrazów nacechowanych emocjonalnie, zależnych od autora. Jednym z nich jest ekspresywizm pompatyczny zawarty w nagłówku artykułu oznaczający 'nadmiar powagi, patosu w czyimś zachowaniu' (por. np. WSJP), wprost komunikujący o nieprzychylnym stosunku metanadawcy do wpisu Trzaskowskiego, ergo do samego Trzaskowskiego. Wyśmiany wpis prezydenta metanadawca poprzedza (ta kolejność jest zamierzona) pozornie neutralnym, dystansującym komentarzem (por. fragment wydaje się, że polityk Platformy delikatnie przesadzit), wyrażającym $\mathrm{w}$ istocie rzeczy gotową ocenę, przedstawiającym arbitralnie zinterpretowaną sytuację i przygotowującym do negatywnego odbioru wpisu Trzaskowskiego oraz do aprobującego przyjęcia komentarzy wyśmiewających. Pozwala to stwierdzić, że metanadawca opowiada się po stronie wyśmiewających - uznaje ich komiczną dezaprobatę za zasadną, a Trzaskowskiego za zasłużenie wyśmianego, i według tego poglądu konstruuje swoją wypowiedź.

Składniki emotywno-oceniające zawarte w leksyce i strukturze tego tekstu służą realizacji perswazyjnych intencji metanadawcy, nakłaniającego odbiorców

25 Za użyciem słowa miszcz w tym kontekście może kryć się również prześmiewcza aluzja do kampanii wyborczej polityka, który w 2015 r., ubiegając się o mandat poselski z krakowskiej listy Platformy Obywatelskiej oraz o sympatię i zaufanie krakowian, wykorzystał w swoim spocie wyborczym regionalizmy krakowskie, m.in. fonetyczne, związane z identyfikacją grup spółgłoskowych trz, strz, szcz itd. (spot został zatytułowany Rafał Trzaskowski czy Czaskowski?). Można więc domniemać, użycie słowa mistrz w wymowie krakowskiej ma służyć przywołaniu, przypomnieniu tych okoliczności i wyśmianiu niekonsekwentnej, relatywnej politycznie postawy Trzaskowskiego. 
do akceptacji i przyjęcia proponowanej przez niego postawy aksjologicznej i emocjonalnej wobec opisywanych faktów i wobec samego polityka. Publiczne pokazanie Trzaskowskiego jako wyśmianego przez internautów ma na celu ujawnienie sztuczności, snobizmu, wyniosłości i przez to podważenie jego reputacji (która powinna być nienaganna) jako kandydata na prezydenta Warszawy. Metanadawca artykułu oczekuje jednoznacznej reakcji odbiorcy na wpis Trzaskowskiego: oburzenia i przyłączenia się do śmiechu internautów. Prowadzić to może do wniosku, że działa w ten sposób na korzyść rywala Trzaskowskiego, jako że, oddając głos socjologowi:

Komizm polityczny zazwyczaj identyfikuje politycznie ludzi i zarazem ujawnia, przez wspólny śmiech, ich łączność. Uprawianie go jest dowodem opowiedzenia się po tej czy innej stronie barykady (...) (Żygulski 1976, s. 119).

Właściwe odczytanie implikowanego w artykule sądu metanadawcy wymaga przywołania szerszego kontekstu sytuacyjnego i społeczno-politycznego oraz włączenia wiedzy dotyczącej organizacji i funkcjonowania władzy politycznej i kampanii wyborczej. Stanowi to o mocy illokucyjnej danego aktu wyśmiania, która w wypadku tego przywołanego artykułu ma wartość perswazyjno-agitującą (wbrew wrażeniu neutralnej informacyjności, jakie chce wywołać metanadawca). Efekt perlokucyjny jest zaś relatywny - wiąże się z indywidualnymi dyspozycjami i preferencjami politycznymi odbiorcy, który, jeśli nie należy do wspólnoty polityczno-ideologicznej metanadawcy i wyśmiewających, może zanegować zajście samego aktu lub zająć wobec niego inne niż perswadowane stanowisko.

\section{Podsumowanie}

Czasownik wyśmiać (kogoś, coś) in vacuo odnosi się do intencjonalnego, niebezpośredniego komunikowania dezaprobaty za pomocą środków komicznych. Jego całościowe znaczenie ujawnia się na styku różnych kontekstów i układów odniesień, które wypełniają każdy ze składników tej ogólnej definicji treścią pragmatyczną. Treści te kształtują pragmatyczne lub - szerzej - dyskursywne znaczenie leksemu wyśmiać (kogoś, coś), które ma charakter dynamiczny. Dynamizm ten można rozpatrywać, jak starałam się to uczynić na wybranym przykładzie tekstu dyskursywnego, w aspekcie pragmatycznego przewartościowania podstawowego znaczenia czasownika wyśmiać (kogoś, coś), odnoszącego się do nieetycznych zachowań osobowych, będących przejawami agresji.

Rodzi to pytanie o to, czy leksem ten nie bywa w wielu wypadkach, jak chociażby w omówionym wyżej tekście, nadużywany i czy nie zaczął (lub zaczyna) funkcjonować jako słowo w służbie tabloidyzujących się mediów. Z drugiej strony, polityka to - jak wiadomo - przestrzeń najbardziej wrażliwa na działanie 
sądów wartościujących (także prześmiewczych), w której ścierają się różne postawy, światopoglądy i ideologie. Komizm odgrywa w niej rolę oręża w rywalizacji o władzę, nazywanej zgoła powszechnie walka, wojna czy bitwą.

\section{Bibliografia}

Austin, John L. (1962). How to do Things with Words. Oxford: University Press, przekład polski W: John L. Austin. Mówienie i poznawanie; rozprawy i wykłady filozoficzne. Przeł. B. Chwedeńczuk, Warszawa: Wydawnictwo Naukowe PWN.

Banasiak, D. (2016). Rozwój semantyczny leksemów śmiać się i śmiech. W: T. Korpysz, A. Kozłowska (red.), Komizm historyczny (59-73). T. VIII. Warszawa: Wydawnictwo Naukowe Uniwersytetu Kardynała Stefana Wyszyńskiego.

Buttler, D. (1974). Polski dowcip językowy. Warszawa: Państwowe Wydawnictwo Naukowe.

Dziemidok, B. (1961). O głównych formach komizmu. Pozyskano z: http://dlibra.umcs. lublin.pl/dlibra/plain-content?id=4240.

Dziemidok, B. (2009). O komizmie. Od Arystotelesa do dzisiaj. Gdańsk: Wydawnictwo słowo / obraz / terytoria.

Greń, Z. (1994). Semantyka i składnia czasowników oznaczających akty mowy w języku polskim i czeskim. Warszawa: Slawistyczny Ośrodek Wydawniczy.

Grochowski, M. (1982). Zarys analizy semantycznej grupy jednostek wyrażających negatywne etycznie relacje osobowe (kpina, zniewaga, upokorzenie). Polonica, VIII, 57-72.

Grzegorczykowa, R., Laskowski, R., Wróbel, H. (red.) (1999). Gramatyka współczesnego języka polskiego. Morfologia. Warszawa: Wydawnictwo Naukowe PWN.

Leibnitz, G.W. (1975). Tablice definicji. W: E. Janus (red.), Słownik i semantyka. Definicje semantyczne (8-89). Wrocław: Ossolineum.

Nowakowska-Kempna, I. (1986). Konstrukcje zdaniowe z leksykalnymi wykładnikami predykatów uczuć. Katowice: Uniwersytet Śląski.

Passi, I. (1980). Powaga śmieszności. Warszawa: Państwowe Wydawnictwo Naukowe.

Peisert, M. (2004). Formy i funkcje agresji werbalnej. Próba typologii. Wrocław: Wydawnictwo Uniwersytetu Wrocławskiego.

Plessner, H. (2007). Śmiech i płacz. Badania nad granicami ludzkiego zachowania. Kęty: Antyk.

Reszka, J. (2001). Predykaty mówienia implikujące pojęcie zła w języku polskim. Kraków: Wydawnictwo Naukowe PWN.

Rudzka-Ostyn, B. (1985). Metaphoric Processes in Word Formation. The case of Prefixed Verbs. Pozyskano z: https://benjamins.com/catalog/cilt.29.11rud.

Zaron, Z. (1980). Ze studiów nad składnią i semantyka czasownika. Wrocław: Ossolineum.

Żygulski, K. (1976). Wspólnota śmiechu. Studium socjologiczne komizmu. Warszawa: Państwowy Instytut Wydawniczy. 


\section{Streszczenie}

Celem artykułu jest próba opisu wybranych właściwości strukturalnych, składniowych i semantycznych czasownika wyśmiać (kogoś, coś), który w izolacji ma ogólne znaczenie 'dezaprobaty wyrażanej za pomocą środków komicznych'. Analiza użyć pokazuje, że leksem ten oznacza złożone akty mowy, których zrozumienie wymaga wieloaspektowej rekontekstualizacji, uwzględniającej perspektywę metanadawcy danego aktu oraz specyfikę komunikacyjną i aksjologiczną dyskursu, w obrębie którego występuje. W artykule omawiam te relacje na przykładzie dyskursu politycznego w Internecie, a konkretnie jednego wybranego z bazy materiałowej tekstu (tzw. newsa), pochodzącego z portalu informacyjnego DoRzeczy.pl. Ich opis pozwala zauważyć, że siła illokucyjna i następstwo perlokucyjne aktów komunikacyjnych, oznaczanych leksemem wyśmiać (kogoś, coś), mają relatywną wartość zależną od punktu widzenia ich odbiorcy. 